\title{
Naturally regenerated English oak (Quercus robur L.) stands on abandoned agricultural lands in Rilate valley (Piedmont Region, NW Italy)
}

\begin{abstract}
Minotta G, Degioanni D
The present study was carried out in 14 sites located in Rilate valley, a hilly area in the south-east Piedmont (NW Italy) within the Monferrato district. Sites were selected where naturally regenerated forest communities are developing on abandoned crop lands. Altitude ranges from 190 to $240 \mathrm{~m}$ a.s.l., while the abandonment period varied from 1 to 50 years at the time of the surveys (year 2007). The presence of younger stands (i.e., stands with age $<12$ yrs) demonstrates a rapid invasion of abandoned farmlands by forest communities dominated by English oak mixed with other hardwoods, such as wild cherry and common elm. Observations conducted in older stands (i.e., stands with age ranging between 20 and 50 yrs) confirm the ability of English oak to generate well structured woodlands in the study area. In these environmental conditions previous cropping and exposure seem to play a significant influence on stand characteristics. Other noble hardwoods, such as wild cherry and common elm, are frequently associated with the oak. These stands showed a mean annual increment varying from 4 to $6 \mathrm{~m}^{3} \mathrm{ha}^{-1}$ year $^{-1}$ at the age of $45-50$ yrs. At the present, black locust is only sporadic in the uppermost canopy layer and generally confined in the understory. The rapid colonization by $Q$. robur is favoured by the presence of adult oak trees in the field edges, providing abundant acorns efficiently dispersed by small rodents and birds. Oak stands observed in this study are worthy of notice in the light of the current decline of many adult oak communities in northern Italy, as well as for their potential to produce lumber and veneer logs. Therefore, these stands should be preserved avoiding coppicing or other irrational cuts. Further studies would be needed to analyze the contribution of soil characteristics to the colonization processes.
\end{abstract}

Keywords: Quercus robur, Abandoned croplands, Oak stands, Piedmont, Rilate valley

\section{Introduction \\ Over the centuries the acreage of Italian forests was markedly reduced to make room for crops, and forest vegetation was gra- dually confined in less favourable sites. Since the early decades of the XX century, many croplands were abandoned especially in mountainous and hilly areas, allowing se-}

Dept. AgroSelviTer, University of Turin, v. Leonardo da Vinci 44, I-10095 Grugliasco (TO - Italy)

\section{(a) Gianfranco Minotta}

(gianfranco.minotta@unito.it)

Received: Apr 23, 2010 - Accepted: Dec 12, 2010

Citation: Minotta G, Degioanni D, 2011. Naturally regenerated English oak (Quercus robur L.) stands on abandoned agricultural lands in Rilate valley (Piedmont Region, NW Italy). iForest 4: 31-37 [online 2011-01-27] URL: http://www.sisef.it/iforest/show.php? id $=560$ condary succession to take place and forest vegetation establishment (Piussi \& Pettenella 2000). These processes generally involve the indigenous pioneer species. A typical case already studied by several authors in Italy are the broadleaf stands dominated by sycamore maple (Acer pseudoplatanus) and European ash (Fraxinus excelsior), colonizing abandoned croplands and grazing areas along the Alps (Garbarino \& Pividori 2006, Pividori \& Bertolotto 2003, Ghidotti \& Piussi 1999, Fontana 1997, Salbitano 1987). So far, less studied are the English oak (Quercus robur) stands developing on former croplands in the south-east of Piedmont (NW Italy), where a progressive abandonment of agricultural lands took place since the middle of the last century, particularly in the hilly areas. This phenomenon is important in relation to the widespread decline occurring in many adult oak communities in northern Italy (Ragazzi et al. 2003, Turco et al. 2006, Bini et al. 2009) that also affects natural regeneration (Scattolin \& Montec- chio 2007). In many cases, the development of oak stands is also disturbed by invasive woody species such as black locust (Robinia pseudoacacia) that is naturalized and widespread in plane and hilly areas of the northern Italy and can exert a strong competition with oaks and other indigenous hardwoods. The present study aims to describe and analyze English oak stands naturally regenerated on abandoned croplands in a hilly area located in the south-east of the Piedmont Region.

\section{Materials and methods}

\section{The study area}

The research was conducted in the Rilate valley $\left(44^{\circ} 58^{\prime} \mathrm{N}, 8^{\circ} 08^{\prime} \mathrm{E}\right)$ in the province of Asti (Monferrato district). The valley encompasses a vast area of approximately 106 $\mathrm{km}^{2}$ that extends from the outskirts of the city of Asti to the neighbouring municipalities. The valley line is rather large and easily cultivable and it is surrounded by several hills with altitudes ranging from 140 to 300 $\mathrm{m}$ a.s.l., where farming is now strongly declining. The average annual rainfall is about $700 \mathrm{~mm}$ with two equinoctial peaks. The average annual temperature is $12.6{ }^{\circ} \mathrm{C}$ and the mean January and July temperatures are 1.5 and $23.1{ }^{\circ} \mathrm{C}$, respectively. Soils are mainly Entisols (IPLA 2001b) derived from sediment deposits attributable to the group of Astiane sands; they are deep, with low developed horizons along the profile. Soil reaction varies from alkaline to sub-alkaline and texture from loam to silty loam.

\section{Field sampling and data processing}

A total of 14 sites where forest communities are establishing on former agricultural lands were selected within the study area (Tab. 1). Altitude ranges from 190 to $240 \mathrm{~m}$ a.s.l. and the timespan since abandonment varied from 1 to 50 years at the time of the surveys (year 2007). The previous crop was mainly vineyard or poplar and hazel plantations. The abandonment was frequently preceded by a period of time during which cultivation practices have been progressively reduced. The year of complete abandonment of farming activities has been deduced through interviews with owners or with other local residents.

In stands aged 12 years or less, 8 plots of 2 x $2 \mathrm{~m}^{2}$ (site 1 ) or 7 plots of $4 \mathrm{x} 4 \mathrm{~m}^{2}$ (sites 2 to 7) in size were delimited on the ground surface along a transect positioned in the middle of the stand in order to minimize the side effect. Inside the plots the height (h) and the species of all woody plantlets with $h>10$ $\mathrm{cm}$ were recorded.

In each stand older than 12 years (sites 8 to 14) a plot of $50 \times 20 \mathrm{~m}^{2}$ in size was deli- 
Tab. 1 - Sites considered in the study.

\begin{tabular}{|c|c|c|c|c|c|c|c|}
\hline $\begin{array}{l}\text { Site } \\
\text { ID }\end{array}$ & $\begin{array}{l}\text { Latitude / } \\
\text { Longitude }\end{array}$ & Site name & $\begin{array}{l}\text { Altitude } \\
\text { (m a.s.l.) }\end{array}$ & Exposure & $\begin{array}{l}\text { Average } \\
\text { slope (\%) }\end{array}$ & $\begin{array}{l}\text { Previous } \\
\text { crop }\end{array}$ & $\begin{array}{c}\text { Years from } \\
\text { abandonment }\end{array}$ \\
\hline 1 & $\begin{array}{l}44^{\circ} 57^{\prime} 58^{\prime \prime N} \\
08^{\circ} 08^{\prime} 04^{\prime \prime} \mathrm{E}\end{array}$ & Mombarone & 230 & SW & 40 & Hazel plantation & 1 \\
\hline 2 & $\begin{array}{l}44^{\circ} 58^{\prime} 07^{\prime \prime N} \mathrm{~N} \\
08^{\circ} 08^{\prime} 06^{\prime \prime} \mathrm{E}\end{array}$ & Mombarone & 230 & SE & 40 & Vineyard & 2 \\
\hline 3 & $\begin{array}{l}44^{\circ} 57^{\prime} 55^{\prime \prime N} \\
08^{\circ} 08^{\prime} 02^{\prime \prime} \mathrm{E}\end{array}$ & Mombarone & 210 & SW & 35 & Hazel plantation & 5 \\
\hline 4 & $\begin{array}{l}44^{\circ} 57^{\prime} 55^{\prime \prime} \mathrm{N} \\
08^{\circ} 08^{\prime} 02^{\prime \prime} \mathrm{E}\end{array}$ & Mombarone & 200 & SW & 25 & Hazel plantation & 5 \\
\hline 5 & $\begin{array}{l}44^{\circ} 57^{\prime} 58^{\prime \prime N} \\
08^{\circ} 08^{\prime} 01^{\prime \prime} \mathrm{E}\end{array}$ & Mombarone & 220 & SW & 20 & Poplar plantation & 9 \\
\hline 6 & $\begin{array}{l}44^{\circ} 57^{\prime} 02^{\prime \prime N} \\
08^{\circ} 09^{\prime} 52^{\prime \prime} \mathrm{E}\end{array}$ & Moncarantino Salice Verde & 250 & SW & 20 & Poplar plantation & 10 \\
\hline 7 & $\begin{array}{l}44^{\circ} 58^{\prime} 13^{\prime \prime N} \\
08^{\circ} 07^{\prime} 48^{\prime \prime} \mathrm{E}\end{array}$ & Mombarone & 220 & NW & 25 & Poplar plantation & 12 \\
\hline 8 & $\begin{array}{l}44^{\circ} 57^{\prime} 50^{\prime \prime N} \\
08^{\circ} 08^{\prime} 01^{\prime \prime} \mathrm{E}\end{array}$ & Mombarone & 190 & SW & 30 & Vineyard & 20 \\
\hline 9 & $\begin{array}{l}44^{\circ} 57^{\prime} 01^{\prime \prime N} \\
08^{\circ} 09^{\prime} 52^{\prime \prime} \mathrm{E}\end{array}$ & Moncarantino Salice Verde & 220 & SW & 45 & Poplar plantation & 25 \\
\hline 10 & $\begin{array}{l}44^{\circ} 58^{\prime} 28^{\prime \prime} \mathrm{N} \\
08^{\circ} 08^{\prime} 10^{\prime \prime} \mathrm{E}\end{array}$ & Mombarone Casegrotta & 230 & SE & 30 & Vineyard & 35 \\
\hline 11 & $\begin{array}{l}44^{\circ} 57^{\prime} 57^{\prime \prime N} \mathrm{~N} \\
08^{\circ} 07^{\prime} 56^{\prime \prime} \mathrm{E}\end{array}$ & Mombarone & 210 & $\mathrm{~W}$ & 35 & vineyard & 40 \\
\hline 12 & $\begin{array}{l}44^{\circ} 57^{\prime} 03^{\prime \prime N} \\
08^{\circ} 09^{\prime} 50^{\prime \prime} \mathrm{E}\end{array}$ & Moncarantino Salice Verde & 240 & SW & 30 & Vineyard & 45 \\
\hline 13 & $\begin{array}{l}44^{\circ} 56^{\prime} 49^{\prime} \mathrm{N} \\
08^{\circ} 07^{\prime} 04^{\prime \prime} \mathrm{E}\end{array}$ & Serravalle Sanna & 190 & SE & 15 & Vineyard & 45 \\
\hline 14 & $\begin{array}{l}44^{\circ} 56^{\prime} 40^{\prime \prime N} \\
08^{\circ} 07^{\prime} 04^{\prime \prime} \mathrm{E}\end{array}$ & Bricco Carlevaro & 240 & $\mathrm{~S}$ & 25 & Vineyard & 50 \\
\hline
\end{tabular}

mited, with the longest side placed along the contour lines; it was always positioned in the middle of the stand to minimize side effects. For all trees with diameter at breast height $(\mathrm{dbh}) \geq 7.5 \mathrm{~cm}$ falling within the plots, the following parameters were recorded:

- species;

- dbh;

- total height;

- height at the insertion of the crown;

- diameter of the crown measured along two orthogonal directions;

- Cartesian co-ordinates.

Within a sub-plot of $4 \times 20 \mathrm{~m}^{2}$ in size placed along the central portion of the main plots, saplings with $\mathrm{dbh}<7.5 \mathrm{~cm}$ and seedlings with height $\geq 10 \mathrm{~cm}$ and $<130 \mathrm{~cm}$ were counted separately for the different species.

For each stand older than 12 years the Square Mean Diameter (SMD), the diameter distribution, the height curve, as well as the total basal area and the standing volume were calculated. The latter was determined using the volume tables of the Italian National Forest Inventory (Castellani et al. 1984). All parameters were reported per hectar after the plot size correction for slope. These stands were also graphically represented through the Stand Visualization System
(SVS) software (McGaughey 2002).

Hierarchical cluster analysis was performed for the younger (age $\leq 12 \mathrm{yr}$.) and older (age $>12$ yr.) stands separately, using the software SPSS 16.0 for WINDOws ${ }^{\circledR}$. The following variables were included in the analyses:

- stands with age $\leq 12$ yr: altitude (m.a.s.l.), slope (\%), years from abandonment; plant density $\left(\mathrm{n} \mathrm{ha}^{-1}\right)$; mean height $(\mathrm{cm})$; percentage of oak plantlets $(\%)$; percentage of cherry plantlets $(\%)$; percentage of elm plantlets (\%); percentage of hazel plantlets $(\%)$; percentage of plantlets belonging to the "other species" (\%);

- stands with age > 12 yr: altitude (m.a.s.l.); slope (\%); years from abandonment; plant density $\left(\mathrm{n} \mathrm{ha}{ }^{-1}\right)$; SMD $(\mathrm{cm})$; percentage of oak plantlets $(\%)$; percentage of cherry plantlets $(\%)$; percentage of black locust plantlets $(\%)$; percentage of plantlets belonging to the "other species" (\%); basal area $\left(\mathrm{m}^{2} \mathrm{ha}^{-1}\right)$; standing volume $\left(\mathrm{m}^{3} \mathrm{ha}^{-1}\right)$; sapling and seedling density $\left(\mathrm{n} \mathrm{ha}^{-1}\right)$.

\section{Results and discussion}

Tab. 2 shows the results of surveys carried out in stands with youngest age among those considered. The total number of individuals per hectare was very variable, with a maxi- mum of about 13400 (site 3) and a minimum of about 3750 (site 6). In all cases oak is the most frequent species, with a maximum of 92.1 and $88.9 \%$ of all individuals surveyed in site 1 and 2, respectively. Only in site 5 oak seedlings are less than $50 \%$ of the total amount. Other species frequent in many of the examined stands are wild cherry (Prunus avium), common elm (Ulmus campestris), hazel (Corylus avellana) and hawthorn (Crataegus spp.). In these early stages of colonization black locust plantlets are infrequent. The mean height reached by oak seedlings is often less than in other species, but generally it increases regularly with timespan since complete land abandonment. In stand 5 both oak and cherry showed a particularly fast growth, probably due to the specific site conditions.

The results show a very rapid colonization of abandoned fields by forest vegetation and a strong pioneering attitude of English oak in the early stage of the secondary succession. A rapid colonization of former cropland by oak was observed in the eastern Netherlands by Smit \& Olff (1998) who noted that this process is linked to the availability of seed in neighbouring areas. In the present study the establishment of forest vegetation probably has already started during the period of re- 
duced cultural activities before the complete abandonment. It is favoured by the adult oak specimens traditionally left by the farmers at the field edges, as well as the dispersal of acorns carried out by animals such as wood mouse (Apodemus sylvaticus) and Eurasian jay (Garrulus glandarius) which are considered very active in seed predation and dispersal in many European oak stands (Jensen \& Nielsen 1986, Den Ouden et al. 2005). The abandonment of agricultural practices can also increase populations of small mammals (Halle 1988, De Bernardi \& Patriarca 2000). Among the other native hardwoods, wild cherry and common elm show the greatest pioneering attitudes in the con- sidered sites. The diffusion of wild cherry can be favoured by the root-sprouting ability typical of this species. On the contrary, black locust exhibits a low invasive potential in the early stages of stand development, possibly due to the low frequency of this species in the adjacent fields and the rapid soil covering by other woody species.

Tab. 3, Tab. 4 and Tab. 5 summarize the results of surveys conducted in stands older than 12 years. Also in these stands English oak was the dominant species in terms of relative abundance (Tab. 3), as well as basal area and standing volume (Tab. 4). In stands with age equal or higher then 40 years, i.e., sites $11,12,13$ and 14 , the calculated volume of oak trees was 121.11, 236.84, 264.66 and $203.51 \mathrm{~m}^{3} \mathrm{ha}^{-1}$, respectively (Tab. 4), corresponding to a percentage of total stand volume varying from 80.6 to $98.8 \%$. Among the other tree species, the most frequent are wild cherry and common elm. Black locust is fairly frequent only in plot 8 , where it reaches a volume of $28.08 \mathrm{~m}^{3}$ $\mathrm{ha}^{-1}$, while it is sporadic or absent in all other stands.

Fig. 1 and Fig. 2 illustrate, respectively, diameter distributions and height curves calculated for site 8 to 14 . In stands 8 to 11 diameter distribution tends to the typical reverse J-curve of uneven-aged forests, while in the older stands 12 to 14 this distribution tends

Tab. 2 - Plant density $\left(n \mathrm{nh}^{-1}\right)$ and mean height $(\mathrm{H}) \pm$ standard deviation in sites with age of abandonment $\leq 12$ yrs.

\begin{tabular}{|c|c|c|c|c|c|c|c|c|c|c|c|c|}
\hline \multirow{3}{*}{$\begin{array}{l}\text { Site } \\
\text { ID }\end{array}$} & \multicolumn{12}{|c|}{ Species } \\
\hline & \multicolumn{2}{|c|}{ English oak } & \multicolumn{2}{|c|}{ Wild cherry } & \multicolumn{2}{|c|}{ Common elm } & \multicolumn{2}{|r|}{ Hazel } & \multicolumn{2}{|c|}{ Other species } & \multicolumn{2}{|r|}{ Total } \\
\hline & $\mathbf{n} \mathbf{h a}^{-1}$ & $\begin{array}{c}\mathbf{H} \\
(\mathbf{c m})\end{array}$ & $\mathbf{n} \mathbf{h a}^{-1}$ & $\begin{array}{c}\mathbf{H} \\
(\mathbf{c m})\end{array}$ & n ha $\mathbf{~}^{-1}$ & $\begin{array}{c}\mathbf{H} \\
(\mathbf{c m})\end{array}$ & n ha ${ }^{-1}$ & $\begin{array}{c}\mathbf{H} \\
(\mathbf{c m})\end{array}$ & $\mathbf{n} \mathbf{h a}^{-1}$ & $\begin{array}{c}\mathbf{H} \\
(\mathbf{c m})\end{array}$ & n ha ${ }^{-1}$ & $\begin{array}{c}\mathrm{H} \\
(\mathbf{c m})\end{array}$ \\
\hline 1 & 10154 & $19.7 \pm 7.9$ & 580 & $35.5 \pm 10.6$ & - & - & 290 & $21.0 \pm 5.7$ & - & - & 11024 & $20.3 \pm 8.5$ \\
\hline 2 & 4062 & $58.6 \pm 42.1$ & - & - & 508 & $30.6 \pm 21.0$ & - & - & - & - & 4570 & 41.2 \\
\hline 3 & 7247 & $75.1 \pm 67.1$ & 758 & $131.5 \pm 80.6$ & 2107 & $113.2 \pm 49.8$ & 2107 & $109.8 \pm 57.6$ & 1180 & $56.9 \pm 78.5$ & 13399 & $78.1 \pm 68.6$ \\
\hline 4 & 5978 & $85.3 \pm 54.4$ & - & - & 780 & $129.8 \pm 61.4$ & 3639 & $61.4 \pm 53.3$ & 1040 & $150.8 \pm 76.1$ & 11437 & $87.1 \pm 62.1$ \\
\hline 5 & 4750 & $190.2 \pm 105.9$ & 4214 & $181.2 \pm 88.3$ & 536 & $38.3 \pm 16.9$ & 1839 & $145.8 \pm 68.7$ & 1149 & $170.5 \pm 87.8$ & 12488 & $172.4 \pm 95.6$ \\
\hline 6 & 2605 & $102.8 \pm 93.5$ & 460 & $76.3 \pm 139.5$ & 77 & $25.5 \pm 3.5$ & - & - & 613 & $228.9 \pm 135.4$ & 3755 & $131.1 \pm 116.9$ \\
\hline 7 & 3866 & $104.8 \pm 85.8$ & 1061 & $144.4 \pm 62.3$ & 152 & $100.0 \pm 84.9$ & 758 & $125.5 \pm 62.3$ & 152 & $108.5 \pm 82.7$ & 5989 & $114.4 \pm 70.8$ \\
\hline
\end{tabular}

Tab. 3 - Plant density $\left(\mathrm{n} \mathrm{ha}^{-1}\right)$ and Square Mean Diameter (SMD) in sites with age of abandonment $>12$ yrs.

\begin{tabular}{|c|c|c|c|c|c|c|c|c|c|c|c|c|}
\hline \multirow{3}{*}{$\begin{array}{c}\text { Site } \\
\text { ID }\end{array}$} & \multicolumn{12}{|c|}{ Species } \\
\hline & \multicolumn{2}{|c|}{ English oak } & \multicolumn{2}{|c|}{ Wild cherry } & \multicolumn{2}{|c|}{ Common elm } & \multicolumn{2}{|c|}{ Black locust } & \multicolumn{2}{|c|}{ Other species } & \multicolumn{2}{|c|}{ Total } \\
\hline & n ha ${ }^{-1}$ & $\begin{array}{l}\text { SMD } \\
\text { (cm) }\end{array}$ & $\mathbf{n} \mathbf{h a}^{-1}$ & $\begin{array}{l}\text { SMD } \\
\text { (cm) }\end{array}$ & $\mathbf{n h a}^{-1}$ & $\begin{array}{l}\text { SMD } \\
\text { (cm) }\end{array}$ & $\mathrm{n} \mathrm{ha}^{-1}$ & $\begin{array}{l}\text { SMD } \\
\text { (cm) }\end{array}$ & $\mathbf{n ~ h a} \mathbf{a}^{-1}$ & $\begin{array}{l}\text { SMD } \\
\text { (cm) }\end{array}$ & n ha ${ }^{-1}$ & $\begin{array}{l}\text { SMD } \\
\text { (cm) }\end{array}$ \\
\hline 8 & 699 & 12.6 & - & - & 201 & 12.4 & 220 & 13.0 & 96 & 12.8 & 1216 & 12.6 \\
\hline 9 & 629 & 15.9 & 9 & 10.0 & 36 & 14.4 & - & - & - & - & 674 & 15.8 \\
\hline 10 & 393 & 16.4 & 29 & 10.0 & 306 & 11.8 & 48 & 11.2 & 57 & 22.1 & 833 & 15.5 \\
\hline 11 & 528 & 17.2 & 245 & 14.4 & 113 & 11.7 & - & - & 28 & 10.0 & 914 & 15.5 \\
\hline 12 & 623 & 22.0 & - & - & - & - & - & - & 77 & 9.4 & 700 & 21.0 \\
\hline 13 & 781 & 20.1 & - & - & 30 & 10.0 & - & - & 10 & 10.0 & 821 & 19.8 \\
\hline 14 & 524 & 22.6 & 29 & 11.9 & 10 & 10.0 & 10 & 25.0 & - & - & 573 & 22.1 \\
\hline
\end{tabular}

Tab. 4 - Basal area $\left(\mathrm{G}\right.$, in $\left.\mathrm{m}^{2} \mathrm{ha}^{-1}\right)$ and standing volume $\left(\mathrm{V}\right.$, in $\left.\mathrm{m}^{3} \mathrm{ha}^{-1}\right)$ in sites with age of abandonment $>12 \mathrm{yrs}$.

\begin{tabular}{|c|c|c|c|c|c|c|c|c|c|c|c|c|}
\hline \multirow{3}{*}{$\begin{array}{l}\text { Site } \\
\text { ID }\end{array}$} & \multicolumn{12}{|c|}{ Species } \\
\hline & \multicolumn{2}{|c|}{ English oak } & \multicolumn{2}{|c|}{ Wild cherry } & \multicolumn{2}{|c|}{ Common elm } & \multicolumn{2}{|c|}{ Black locust } & \multicolumn{2}{|c|}{ Other species } & \multicolumn{2}{|c|}{ Total } \\
\hline & G & $\mathbf{V}$ & G & $\mathbf{V}$ & G & $\mathbf{V}$ & G & $\mathbf{V}$ & G & $\mathbf{V}$ & $\mathbf{G}$ & $\mathbf{V}$ \\
\hline 8 & 8.68 & 54.84 & - & - & 2.42 & 13.85 & 2.9 & 28.08 & 1.23 & 10.92 & 15.22 & 107.69 \\
\hline 9 & 12.52 & 95.29 & 0.07 & 0.41 & 0.59 & 3.2 & - & - & - & - & 13.18 & 98.89 \\
\hline 10 & 8.25 & 74.39 & 0.23 & 2.51 & 3.36 & 21.49 & 0.47 & 2.97 & 2.20 & 23.57 & 14.51 & 124.94 \\
\hline 11 & 12.32 & 121.11 & 3.97 & 23.48 & 1.21 & 4.95 & - & - & 0.22 & 0.62 & 17.72 & 150.16 \\
\hline 12 & 23.61 & 236.84 & - & - & - & - & - & - & 0.53 & 5.24 & 24.14 & 242.08 \\
\hline 13 & 24.83 & 264.66 & - & - & 0.23 & 1.67 & - & - & 0.08 & 1.62 & 25.14 & 267.96 \\
\hline 14 & 20.98 & 203.51 & 0.33 & 1.65 & 0.08 & 0.21 & 0.48 & 3.50 & - & - & 21.85 & 208.88 \\
\hline
\end{tabular}


Tab. 5 - Density of saplings $\left(\mathrm{n} \mathrm{ha}^{-1}\right)$ with dbh less than $7.5 \mathrm{~cm}$ and seedlings with height $\geq 10 \mathrm{~cm}$ and $<130 \mathrm{~cm}$ in sites with age of abandonment $>12$ yr.

\begin{tabular}{|c|c|c|c|c|c|c|c|c|c|c|}
\hline \multirow{2}{*}{$\begin{array}{l}\text { Site } \\
\text { ID }\end{array}$} & \multicolumn{10}{|c|}{ Species } \\
\hline & $\begin{array}{c}\text { English } \\
\text { oak }\end{array}$ & $\begin{array}{l}\text { Wild } \\
\text { cherry }\end{array}$ & $\begin{array}{c}\text { Common } \\
\text { elm }\end{array}$ & $\begin{array}{l}\text { Black } \\
\text { locust }\end{array}$ & Hazel & $\begin{array}{l}\text { European } \\
\text { hackberry }\end{array}$ & $\begin{array}{c}\text { Sweet } \\
\text { chestnut }\end{array}$ & $\begin{array}{l}\text { Hedge } \\
\text { maple }\end{array}$ & $\begin{array}{c}\text { Other } \\
\text { species }\end{array}$ & Total \\
\hline 8 & 2385 & 192 & 2739 & 220 & 10 & 527 & - & - & 336 & 6409 \\
\hline 9 & 118 & 53 & 64 & 18 & - & - & 27 & - & - & 280 \\
\hline 10 & 27325 & 4646 & 4377 & 10 & 1245 & 193 & - & - & 1101 & 38897 \\
\hline 11 & 1123 & 2680 & 6154 & - & - & 142 & - & - & 1567 & 11665 \\
\hline 12 & 402 & 2212 & - & 1580 & - & - & 891 & - & - & 5085 \\
\hline 13 & 22092 & 2265 & 2195 & 346 & 22270 & - & 148 & 1038 & 10 & 50364 \\
\hline 14 & 552 & 6583 & 356 & 2007 & - & - & 396 & - & - & 9894 \\
\hline
\end{tabular}

to the bell curve typical of even-aged forests. tively, and representative of the vertical an almost uniform structure as expected These data suggest an increase in the stand structures occurring in the examined self-restructural homogeneity along with the age of the community, probably due to the slowing of regeneration processes subsequent to soil covering by tree crowns. Fig. 3 and Fig. 4 report the perspective view realized with the SVS software for stands 11 and 12 , respecgenerated oak stands after the establishment phase. Stand 11 (Fig. 3) exhibits a stratified vertical structure with oak crowns in the uppermost canopy layer and the other hardwoods (wild cherry and common elm) in the lower layer, while stand 12 (Fig. 4) exhibits from the pattern of the diameter distribution (Fig. 1).

Regarding saplings with dbh less than 7.5 $\mathrm{cm}$ and seedlings with height $\geq 10 \mathrm{~cm}$ and $<$ $130 \mathrm{~cm}$, the most frequent species were oak, wild cherry, common elm and black locust (see Tab. 5). The relative abundance of these
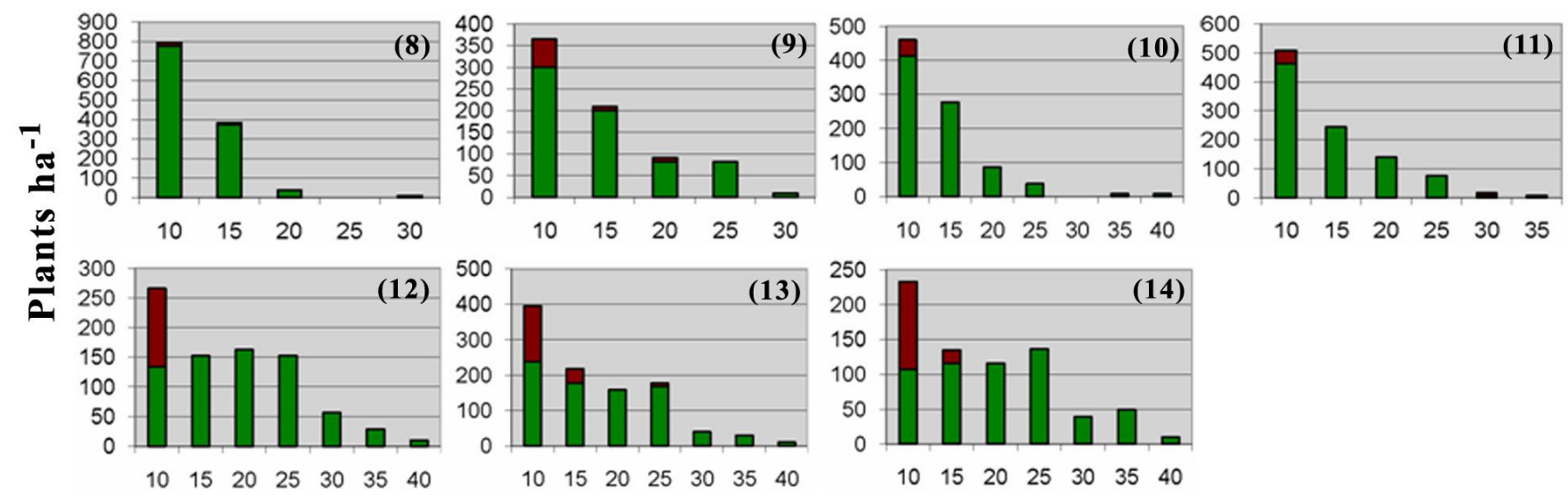

Diameter Class (cm)

Fig. 1 - Diameter distribution in stands 8 to 14. Green and brown colours indicate alive and dead plants, respectively.
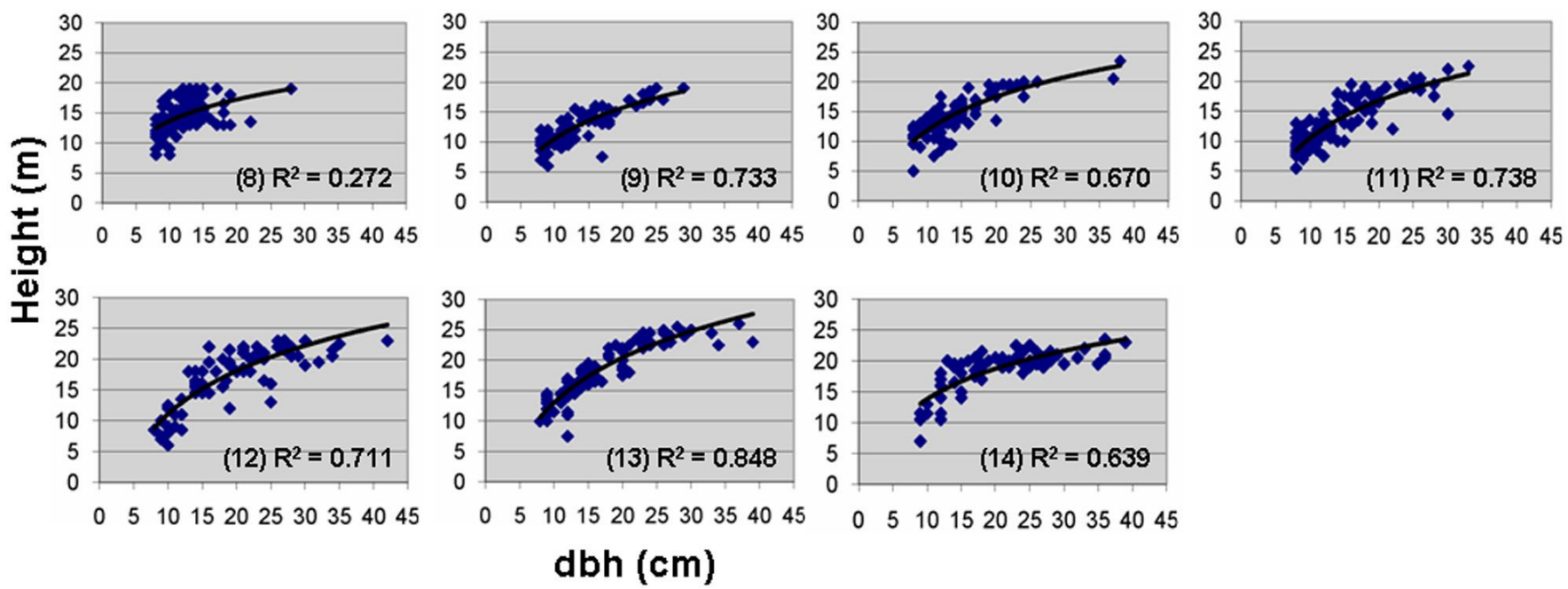

Fig. 2 - Height curves calculated for stands 8 to 14. 
Fig. 3 - Perspective view relative to stand 11 realized with SVS software. Dark green crowns represent English oak trees and light green crowns cherry, elm and "other species" trees brick-red stems represent dead trees.

Fig. 4 - Perspective view relative to stand 12 realized with SVS software. Dark green crowns represent English oak trees and light green crowns trees belonging to "other species"; brick-red stems represent dead trees.
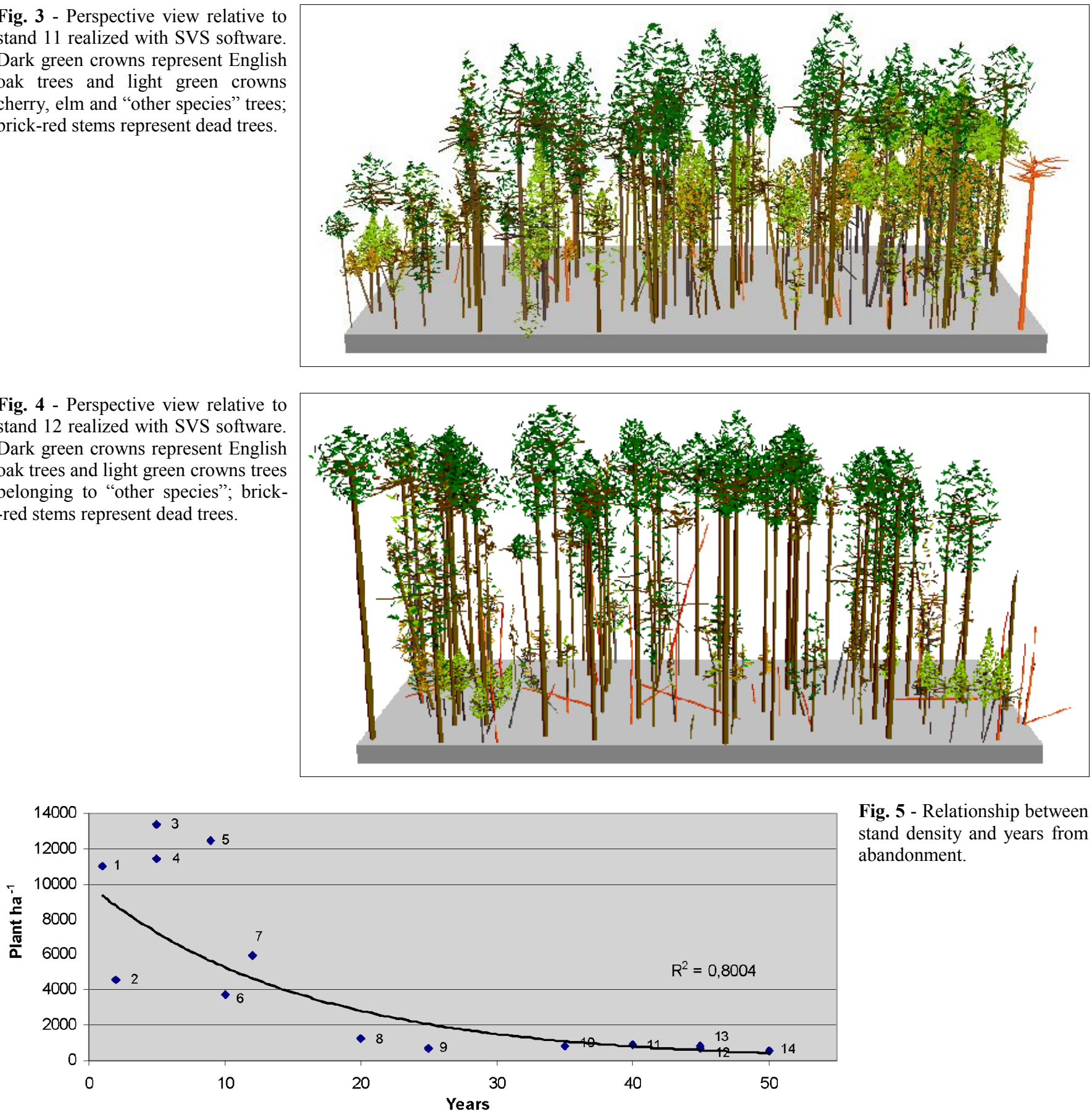

Fig. 5 - Relationship between stand density and years from abandonment.

Fig. 6 - Relationship between stand volume and years from abandonment.

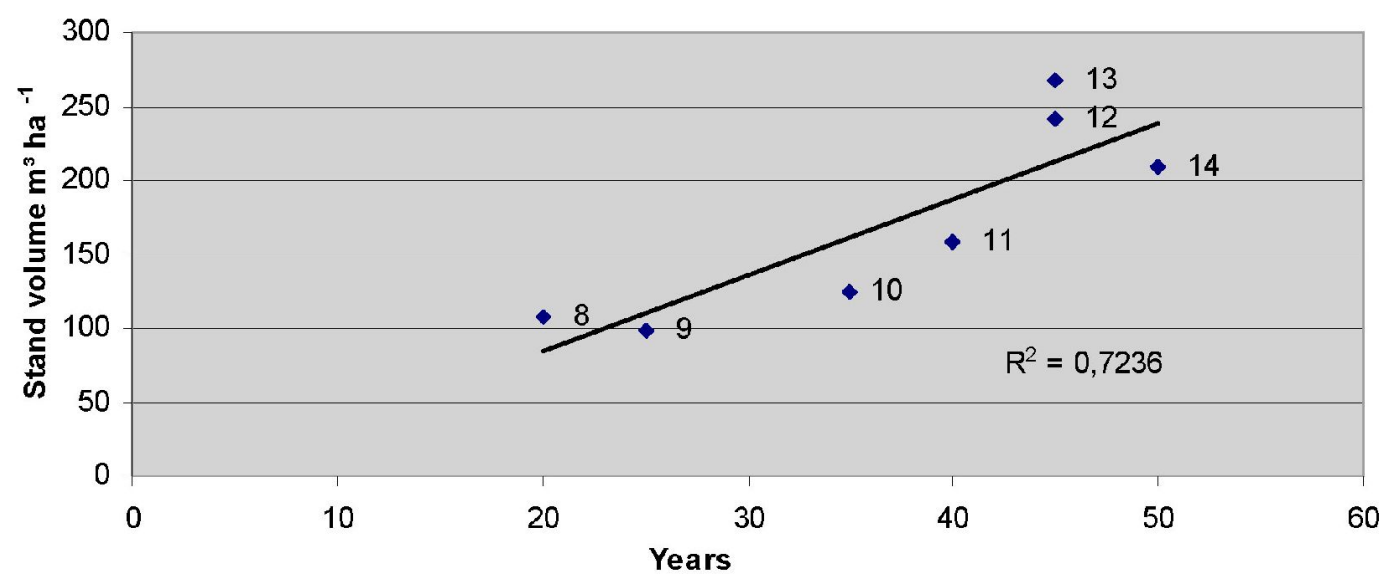




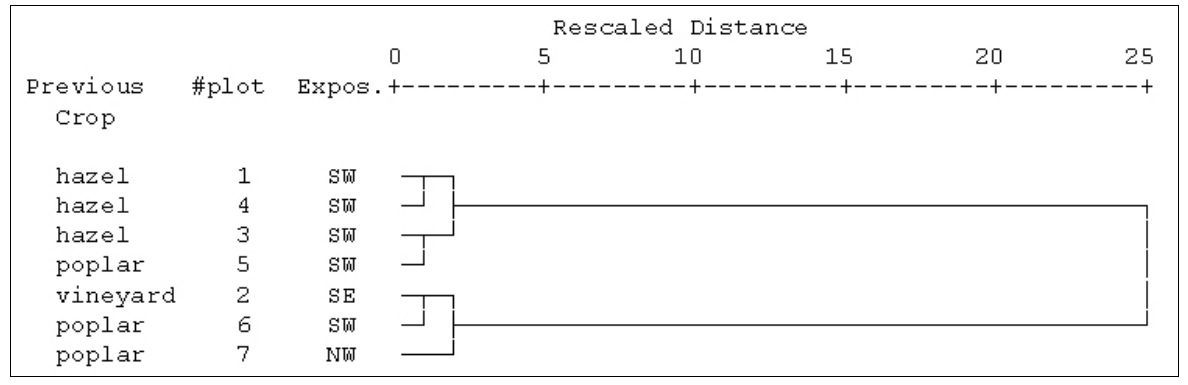

Fig. 7 - Results of the hierarchical cluster analysis for stands with age $\leq 12$ years: dendrogram using Square Euclidean Distance method.

species was widely different in the various plots. It is interesting to note that other indihackberry (Celtis australis) and Edge maple (Acer campestre) are present in some stand at the understory level.

The results obtained in stands aged between 20 and 50 years show that English oak tends to maintain the dominance within the forest community also in the stages subsequent to the early establishment of tree species. Also the most frequent accompanying species, i.e., wild cherry and common elm, are the same already observed in the younger communities.

With few exceptions, black locust is still sporadic in the uppermost canopy layer, while its presence is sometimes significant in the understory, especially in older stands of dominant trees is relatively high. Fig. 5 and Fig. 6 show, respectively, the trend in stand density and volume according to years from abandonment. As expected, stand density decreases exponentially with increasing the age of the forest community. The reduction rate tends to be more rapid in the first 20 years from abandonment (Fig. 5), when intra- and inter-specific competition is probably more intense. After 50 years from abandonment (site 14) the density is about 570 plants ha $^{-1}$. Stand volume increased linearly with the years from abandonment (Fig. 6); this is consistent with the relatively young age of the examined communities and it is also indicative of their good health congenous woody species such as European where the light availability under the crown

ditions. Demographic and volumetric values observed in the present study are similar to those reported for mixed English oak-common hornbeam stands growing in the hills along the Po river (IPLA 2001a).

Fig. 7 and Fig. 8 show the results of the cluster analysis carried out for the stands with age $<12$ years and $>12$ years, respectively. For the younger stands the analyses identifies two main groups, the first one including 4 plots with SW exposure and hazel or poplar plantations as previous crop, the second including 3 plots with various exposure and poplar plantations or vineyard as previous crop. For the older stands also cluster analysis separates two main groups; the first one formed by 5 plots with SW, W or $\mathrm{S}$ exposure, including the only older stand with poplar instead of vineyard as previous crop, the second formed by 2 plots both with SE exposure. As expected, these results confirm that previous cropping conditions as well as site exposure may exert a marked influence on the development of the studied stands. The effect of previous cropping conditions is appreciable within the younger stands, where "hazel" plots are clearly grouped (Fig. 7). The effect of site exposure appears particularly evident within the older stands, where the influence of the previous cropping conditions may be declining. In fact, in this case sites with SE aspect have been clearly separated from the other plots (Fig. 8). On the other hand, since the study area exhibits only small altitudinal variations, slope exposure can be taken as the

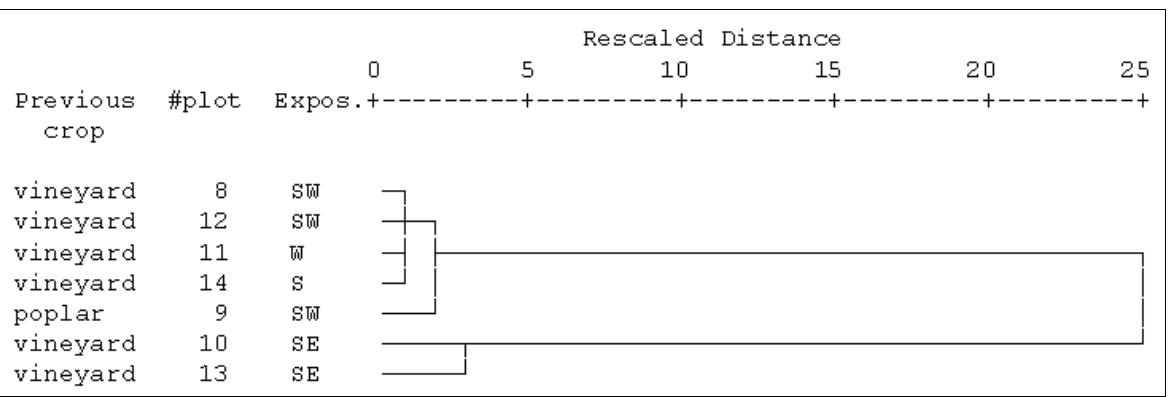

Fig. 8 - Results of the hierarchical cluster analysis for stands with age $>12$ years: dendrogram using Square Euclidean Distance methods. main factor determining microclimate characteristics at the observed sites.

\section{Conclusions}

The analysis conducted in this study shows a strong attitude of English oak to develop well structured stands, where it is the dominant species, on former agricultural lands located in the hilly areas of south-east Piedmont. Other noble hardwoods, such as wild cherry and common elm, are frequently associated with the oak. The mean annual increment of these stands varies, approximately, from 4 to $6 \mathrm{~m}^{3} \mathrm{ha}^{-1}$ year ${ }^{-1}$ at the age of $45-50$ yrs. These observations coincide with those conducted by Onaindia et al. (2001) who studied forest communities naturally regenerated on former cropland in the northeastern France. They found, after 50 years from the abandonment of agricultural practices, the establishment of mixed hardwood stands of sessile and pedunculate oak, beech, wild cherry and rowan with good structural characteristics.

The colonisation ability showed by English oak in this study may be partly referred to the availability of acorns provided by the adult trees growing in the field edges, as well as the effective dispersion activity of small rodents and birds. However, further studies would be needed to analyze the contribution of soil physical, chemical and biological traits to these processes. Some authors have stressed the influence of soil richness on the colonization of abandoned fields by the forest vegetation (Smit \& Olff 1998), while the presence of mycorrhizae can increase the adaptability of tree species to site conditions (Boelke \& Kahle 2008).

On the whole, the forest stands described in this study are worthy of notice in the light of the already mentioned decline occurring in many adult oak communities in northern Italy, as well as for their potential to produce lumber and veneer logs. Therefore these stands, which usually belong to private owners, should be carefully preserved, avoiding coppicing or other irrational cuts which may favour the black locust individuals already present in the understory. At the present, moderate selective thinnings could be applied to favour the best stems providing simultaneously small wood for energy purposes. Anyway, these communities should be monitored across time in order to verify any change in species composition, structure and vegetative conditions.

\section{References}

Bini C, Buffa G, D’Onofrio E, Zilioli DM (2009). Soil and land qualities influence forest decline in the Venetian plain (NE Italy). In: "Proceedings of the air water and soil quality international congress" (Manos Dassenakis A, Pattee E, Vianello G, Vittori Antisari L eds). Imola (Italy) 24-25 June 2009, vol. 3, pp. 175-182. 
Boelke B, Kahle P (2008). Energy forestry with willows and poplars - yields and nutrient supply. Pflanzenbauwissenschaften 12: 78-85.

Castellani C, Scrinzi G, Tabacchi G, Tosi V (1984). Inventario forestale nazionale italiano. Tavole di cubatura a doppia entrata. Ministero dell'Agricoltura e delle Foreste, Istituto Sperimentale per l'Assestamento Forestale e per 1'Alpicoltura, Trento (Italy), pp. 114

De Bernardi P, Patriarca E (2000). I mammiferi delle aree protette astigiane: inventario e caratterizzazione ecologica preliminare. Quaderno ${ }^{\circ} 2$, Ente dei Parchi e delle Riserve Astigiani, pp. 32.

Den Ouden J, Jansen PA, Smit R (2005). Jays, mice and oaks: predation and dispersal of Quercus robur and $Q$. petraea in north-western Europe. In: "Seed fate: predation, dispersal and seedling establishment" (Forget PM, Lambert JE, Hulme PE, Vander Wall SB eds). CABI publishing, Wallingford, MI, USA, pp. 223-240.

Fontana S (1997). Boschi di neoformazione: un caso nelle Prealpi venete. Sherwood-Foreste ed alberi oggi 3: 13-17.

Garbarino M, Pividori M (2006). Le dinamiche del paesaggio forestale: evoluzione temporale del bosco di neoformazione sui pascoli di Corte Pogallo - Parco nazionale della Val Grande (VB). Forest@ 3: 213-221. - doi: 10.3832/ efor0359-0030213

Ghidotti N, Piussi P (1999). Rimboschimento spontaneo di coltivi abbandonati nelle Alpi orobiche. Atti del II Congresso S.I.S.E.F.: “Applicazioni e Prospettive per la Ricerca Forestale Italiana" (Bucci G, Minotta G, Borghetti M eds). Ed. Avenue media, Bologna (Italy), pp. 23-26.

Halle S (1988). Mammal fauna in a young reclaimed area in the Rhineland lignite region. Zeitschrift für Angewandte Zoologie 75: 421427.

IPLA (2001a). Boschi collinari. Regione Piemonte, Collana Blu, Torino, pp. 119.

IPLA (2001b). Carta dei suoli 1:50000 on line. Regione Piemonte, Torino, Italy. [online] URL: $\mathrm{http}: / / \mathrm{www}$. regione.piemonte.it/agri/suoli_terreni/ipla.htm

Jensen TS, Nielsen OF (1986). Rodents as seed dispersers in a heath-oak wood succession. Oecologia 70: 214-221. - doi: 10.1007/BF00379242

McGaughey RJ (2002). Stand Visualization System, version 3.36. Gen. Tech. Rep. PNW-0000, USDA Forest Service, Pacific Northwest Research Station, Portland, OR, USA. [online] URL: http://forsys.cfr.washington.edu/

Onaindia A, Gegout JC, Piedallu C, Nicolescu NV, Bastien Y (2001). Research on forest vegetation naturally regenerated on abandoned agricultural, vine growing, orchard and pasture lands in the Amance-Apance region (Haute-Marne County, France). Revista Padurilor 116: 19-26.

Piussi P, Pettenella D (2000). Spontaneous affor- estation of fallows in Italy. NEWFOR - New forests for Europe: Afforestation at the turn of the Century. EFI Proceedings 35: 151-163.

Pividori M, Bertolotto G (2003). Analisi strutturale ed evolutiva in acero-frassineti di neoformazione delle valli di Lanzo (TO). Monti e Boschi 5: 34-40.

Ragazzi A, Moricca S, Capretti P, Dellavalle I, Turco E (2003). Differences in composition of endophytic mycobiota in twigs and leaves of healthy and declining Quercus species in Italy. Forest Pathology 33: 31-38. - doi: 10.1046/ j.1439-0329.2003.3062003.x

Salbitano F (1987). Vegetazione forestale ed insediamento del bosco in campi abbandonati in un settore delle Prealpi Giulie (Taipana-Udine). Gortania 9: 83-144.

Scattolin L, Montecchio L (2007). First report of damping-off of common oak plantlets caused by Cylindrocladiella parva in Italy. Plant Disease 91: 771. - doi: 10.1094/PDIS-91-6-0771B

Smit R, Olff H (1998). Woody species colonisation in relation to habitat productivity. Plant Ecology 139: 203-209. - doi: 10.1023/A:10097502 16223

Turco E, Marianelli L, Vizzuso C, Ragazzi A, Gini R, Selleri B, Tucci R (2006). First report of Botryoshaeria dothidea on sycamore, red oak and English oak in Northwestern Italy. Plant Disease 90: 1106. - doi: 10.1094/PD-90-1106B 